\title{
Principal Leadership in Developing School Culture
}

\author{
Mohammad Ali Ridho \\ Departement of Management Education \\ Universitas Negeri Surabaya \\ Surabaya, Indonesia \\ mohammadridho@mhs.unesa.ac.id
}

\author{
Murtadlo \\ Departement of Management Education \\ Universitas Negeri Surabaya \\ Surabaya, Indonesia \\ murtadlo@unesa.ac.id
}

\author{
I Ketut Budayasa \\ Departement of Mathematic Education \\ Universitas Negeri Surabaya \\ Surabaya, Indonesia \\ ketutbudayasa@unesa.ac.id
}

\begin{abstract}
The Principal's leadership plays an important role in cultivating a school culture. The aim of this study was to analyze the principal's leadership in an attempt to develop a positive school culture and its impact on school achievement. A qualitative approach with case study was used. The study was conducted in a Primary School. The data were obtained from interview, observation and documentation. The results of this study showed that the application of participative leadership style at school was good to support the creation of a positive school culture. The principal also made several efforts through the development of harmonious relationships, school security and school environment that conducive for learning process. Positive developed school culture impacted on school achievements. This study found a significant role of the principal in developing the school culture through leadership styles and several efforts. The important point for further research is concerning with development of leadership and school culture to improve school quality.
\end{abstract}

Keywords-principal's leadership; positive school culture; school culture development; school achievement.

\section{INTRODUCTION}

Leadership and school culture are two words that always combined together especially with the theme of school quality improvement. A good and quality school must have positive habits that must be developed by a principal. Understanding school culture well is an important key of school principals to improve their schools' quality. There is a substantial evidence in the literature to suggest that a school principal must understand first the school culture before implementing the change [1]. All the other roles and responsibilities of a school principal are important, but a positive school culture is imperative [2]. Also result of testimonies from successful school principals suggests that focusing on development of the school's culture as a learning environment is fundamental to improved teacher morale and student achievement [3]. Therefore, attention to school culture is a top priority in the principal's leadership. School principals who choose to lead rather than just manage must understand first the school's culture. It is important to realize that culture is complex because it has unique and idiosyncratic ways of working [3]. The complexity of school culture looks like in the definition of culture that is the underground stream of norms, values, beliefs, traditions, and rituals that have built up over time as people work together, solve problems and confront challenge[4]. Specifically, the school culture is also defined as the basic assumptions, norms and values, and cultural artifacts that are shared by school members, which influence their functioning at school [5]. These definitions show that school culture will forms an identity of school. So, it can be said that the quality of schools depends on the growing school culture in its schools. The more positive the school culture develops, the more achievers the learners will ultimately improve the quality of schools. Even school culture can determine the life and death of a school organization, without a strong and positive culture, schools flounder and die [6]. Here, we know the importance of school culture. Culture takes an important point to make an influence of an organization in order to create effective schools, which are capable to achieve the school goals. Principals with the knowledge of their school's culture enable to understand the influence of culture on measurable outcomes, which is important to increase student achievement [7], and to impact the organization performance [8].

But all this time, the application of the program for the improvement of school quality conventionally always relies on improving the quality of teaching and learning process, little touch of the leadership aspect and management and do not touch the cultural aspects of the school [9]. This is unfortunate, considering the importance of school leadership and culture in an attempt to improve the quality of schools. Therefore, the school needs a leader who has an understanding in developing school culture, so that it can lead to the establishment of a positive school culture that supports the achievement of schools. The principal is expected to play his role as a leader in influencing all the components of the school to jointly build a positive school culture. A strong and positive school culture does not just happen, they are built from time to time by those 
who work inside, attend school and lead formal and informal that encourage and strengthen values and traditions [6]. A positive school culture will encourage all school members to work together, invite the participation of all citizens, encourage new ideas, and provide opportunities for renewal in schools that all lead to the achievement of the best outcomes.

Due to the importance of school culture, the development of positive school culture becomes non-negotiable. The realization of a strong school culture certainly cannot be separated from the leadership role of a principal. The principal is the most responsible and influential person to determine all the activities and policies that all school citizens must undertake. As the leaders of educational institutions, he has the greatest potential and plays a key role in shaping and developing a strong school culture. He has a duty in instilling awareness, and appreciation of the positive values that should be cultivated in the school he leads [10]. The development of positive school culture will not work optimally without qualified principals' leadership. The quality of leadership in schools has an important role in improving the quality and effectiveness of schools. When talking about leadership, the key word is influencing others. Leadership is as a process for influencing others to understand and agree on what needs to be done and how to do it, and the process of facilitating individual and collective efforts to achieve common goals [11]. In fact, leading a school as an organization is not easy. A principal is required to adjust his or her leadership style and behavior and is also required to always increase his role as a suitable leader in school. The maximum leadership role of principal gives a considerable influence in developing the school culture. In this context, the quality of leadership can be seen from how big the principal plays a role in influencing and guarding staff and school components to jointly cultivate positive values within the school environment.

Several studies indicate the importance of school culture and its correlation to school quality improvement. Study of 29 Texas schools about School Culture Implications on Academics School culture showed that a school's culture could have a positive or negative effect on success. Schools with more solid cultures that leaders understood have better scores and increase teachers' satisfaction. This study shows the impact that school culture has on the performance of a school site [3]. Study of 270 junior high schools in Medan Indonesia showed that there is a significant relationship between principal leadership and school culture together with school effectiveness. It can be concluded that the principal's leadership and school culture are related to the quality of schools. This means that the quality of leadership in developing the school culture will have an impact on improving the quality of schools [12]. Another studies conducted in performance in State Senior High School in Tasikmalaya Indonesia showed a significant influence of organizational culture on school [13]. These studies used a quantitative approach that cannot reveal in depth about leadership and school culture in school institutions. To conduct an in-depth study, qualitative studies are required in the field. This is an attraction for me as a researcher to conduct qualitative research in schools about how the principal's leadership in an effort to develop a positive school culture and how it impacts on performance improvement and school performance. This was what made it different from other studies. This research was conducted at a primary school. The purpose of this study is to describe the principal leadership style, the role of school principal in an attempt to develop a positive school culture and the impact of school culture development on school quality improvement that can be measured from the school achievement.

\section{METHOD}

To study deeply the principal leadership in developing school culture and its impact to school performance, this study performed a qualitative research with a case-study approach. The selection of this method is based on the purpose of studies that is to understand the principal's leadership in developing a positive school culture through the exploration of daily activities and principal interactions as a leader in a real context. Case study research method is as an empirical inquiry that investigates a contemporary phenomenon within its real-life context; when the boundaries between phenomenon and context are not clearly evident; and in which multiple sources of evidence are used [14]. Purposive and snowball sampling techniques are used in this study. The subjects of research are the principal, vice of the principal, teachers, students, parents, and school committee. Generally, data collection techniques used in this research is qualitative research techniques such as participant observation, in-depth interviews, and documentation [15]. To test the validity of the data, the researcher used four main criteria to ensure the reliability of qualitative research results through credibility, transferability, dependability, confirm ability [16]. After the data was collected, then the data was analyzed using descriptive analysis technique which was done through three steps including: data collection, data condensation, data display, and conclusion [17]. The sequence of data analysis process is as shown in Figure 1.

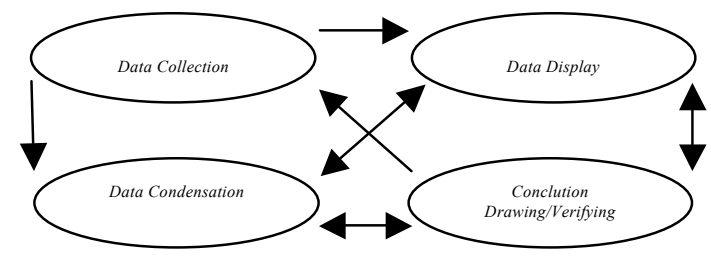

Fig. 1. Data Analysis Components [17]

The steps of data analysis are as follows: first, data collection. Data collection used in this research is observation, interview and documentation study. A collection of data on the principal's leadership in developing school culture obtained descriptively is a record of what the researcher sees, observes, and experiences in school. The second one is data condensation. Data condensation was used by the researcher to simplify the data, this simplification was done after the data was obtained then summarized and taken important sections that are related to the research focus. The third one is data display. Display or presentation of data is a process of displaying data simply in the form of words, sentences, 
narratives, tables, matrix, and graphics. In this study, researchers present data in the form of words, sentences, narratives, tables or matrices. Presentation of such data will provide a comprehensive picture, organized, arranged in a relationship pattern to be easily understood. The fourth one is data conclusion and verification. Conclusion drawing is the final activity of data analysis. This conclusion is made by interpreting existing categories and combining them by looking at the relationships among the data so that it can be known thoroughly about the principal's leadership in developing positive school culture.

\section{RESULT AND DISCUSSION}

\section{A. Principal Leadership Style}

Based on the data, the principal dominantly implemented a participative leadership style. It is reflected in his behaviors and roles in performing daily tasks. He is not just behind the scenes but he becomes a pioneer by being actively involved in programs and agendas organized by school, especially in an attempt to build a positive school culture. For example, in growing discipline, he actively participates by trying to be present in time to be a role model for all components within the school environment. This is done by the principal to encourage participatory attitudes of all school components in implementing school programs. The implementation of participative leadership style makes the principal have a close relationship and familiar with staff, this is a plus point for the principal in establishing good cooperation with all components of the school [18] and it will build an assumption that nothing is difficult and there is no reason not to work, thus will build a culture of close cooperation through empowerment of staff, in this case teachers and employees in implementing school programs [19]. This empowerment indicates that the principal does not work on his own programs but is delegated to staff according to his or her respective duties. This may eliminate a paradox or assumption that the principal is a one man show in the succession of school programs. The principal gives clear duties and authority to his staff according to their main duties and functions contained in their job description. Empowerment is a part of participative leadership because participative leadership also empowers the subordinates [20], even empowerment is a form of intrinsic motivation to be involved in cultural change [21].

This participative leadership style is good and suitable to be used in developing positive school culture. Marc Timmerman [22] wrote an article about "How Participative Leadership Powers a Culture of Productivity" he argued that in good times and in bad, participative leadership can greatly influence company culture. The power of participative leadership to affect culture and productivity is well documented in academic literature. For example he cited result of several researchers as follows: people perform better in a participative environment; participative leadership style improves the innovative behavior of employees; participation is one of the levers that create higher employee satisfaction. Participative leadership has a positive and significant impact on all the facets of organizational culture. It, therefore, suggested that participative leadership styles are effective in adapting organizations environments to achieve and sustain these desired cultural values. However, participative leadership was found to be the best style to effect these cultural changes [23].

\section{B. The Role of Principal Leadership in an Attempt on Developing Positive School Culture}

As a leader, a principal has a vital role in developing positive school culture. Based on the results of the research, the principal makes some efforts in developing positive school culture. Some of these efforts are three main areas of principal's duty to build conducive school condition [24].

\section{1) Harmonious relationship development.}

The effort of the principal in developing a positive school culture is to develop harmonious relationships with all components of the school. It is as one of the effective principal leadership criteria to establish harmonious relationships with the community so as to actively involve them in order to realize the vision and mission of the school as well the purpose of the school. Besides, the principal can work collaboratively with the school management team [25]. To realize a harmonious relationship, the principal do several ways such as, intensity of communication through formal and non-formal approaches. Formal approach is done through regular meetings with teachers weekly and monthly, meeting with student's parents, bimonthly meeting with school committee; and nonformal approach is done through istighosah, reciting al-Qur'an together, chatting in WhatsApp group, and seven-minute lecture known as kultum. The intensity of communication is not only with the teachers but with all components of the school including the committee, student's parents and community in general. This has an effect on harmonious relationships within the school environment and can increase participation towards more quality school development. The intensity of communication with these approaches indicates the effectiveness of principal who has the leading skills and knowledge to bringing together all stakeholders in achieving common goals [26]. Good communication skills are also part of the human skill that a principal must master in performing his duties as a school leader. Due to the fact that the principal's job is to work with and through others, he must behave as a communication channel in the school environment to increase participation by doing collaboration [27].

Another effort to develop a harmonious relationship is by increasing the participation of the school community. Increased participation is done in several ways, including through the involvement of school residents in school policy programs. The effort of the principal can improve the relationship of the school community more harmonious. This harmony will establish good cooperation and collaboration among the citizens of the school so as to create a positive school culture. The principal's efforts in increasing participation and cooperation are done with all school residents, both within the school and outside the school environment. Creating a positive and safe learner environment, effective school leaders involve the entire school community, including students, staff, parents, and members of the school community by trying to build interpersonal relationships with the community [28].

\section{2) School security development.}

School security development is another effort done by the principal to ensure the safety of the citizens of the school, thus 
all the citizens of the school feel at home and happy to go to school. This effort is appropriate, because a school is a place of interaction and collection of learners who have many differences that sometimes can cause friction between each other. The security development effort by the principal is also a preventive effort against the things that are not desirable. Prevention of accidents in schools is the task of school leaders both legally and ethically. In the case of student accidents, $58 \%$ were reported for lack of proper supervision [29]. Data from the National School and Staffing Survey (SASS) in the United States found that challenges to school rules and security were always present at any school, whether public schools, government schools or private schools [28]. School security is the responsibility of the principal, maintaining a safe learning environment that is free from hazards and distractions has more implications than positive school climate. The principal must proactively handle and monitor applicable law-based security issues [28].

Several efforts have been made by the principal to develop school security through written regulations, teacher integrity pact, student control card also known as KKS, security support facility, security guard, procurement of suggestion box, and also slogans posterized in banner. In addition, the principal's efforts in developing school security are also through the development of 5S habituation (senyum, salam, sapa, sopan, santun) or also interpreted as smile, greeting (with Arabic or Islamic languages), greeting, polite, courteous.

\section{3) Develop a school environment conducive to learning.}

Based on the results of the research, the principal also does some other efforts in developing a positive school culture by developing a conducive environment and atmosphere. Here are some of the principal's efforts in developing a conducive school environment.

The development of the religious environment is done by instilling the behavior systematically in the form of habituation program in practice the worship of amaliyah so that formed a personality and the good attitude, also known as akhlaq alkarimah. It will have implications on the creation of a conducive environment. The habituation program is reciting the holy Qur'an in the morning for 1 hour, praying before and after learning, dhuhur and ashar prayer in the school, suggestion for polite dress, tahfidz program.

Another effort of the principal in developing a conducive school environment is also done by creating a clean and healthy academic environment. To realize this, the principal applies the rules in maintaining the cleanliness of the school environment such as scheduling class picket, empowering the cleaning staff in charge of maintaining cleanliness throughout the school environment, mentoring morals, and giving motivations in various occasions, in meetings, kultum, and through the chatting in media whatsApp group. In addition, to build a clean school, the principal posterized in the form of slogans, placards and banners calling for cleanliness.

Increasing discipline is also the effort in developing a conducive school environment. Discipline is very important in educational process, the school must have a written rule as the foundation of discipline (rules of binding order) to be followed and applied by every student and all the citizens of the school
[30]. Increased discipline is done by principal through monitoring, modeling, fingerprint for teachers and learners, reward and punishment system, and pasteurization containing disciplinary messages. These efforts have significant improvements in discipline of students, teachers and staff. The discipline elements an institution should own in educating children to behave as expected are rules of order, rewards, punishment and consistency [31].

Another principal's effort in developing a conducive environment is to build a culture of competition. It is built in order to provide strong motivation and encouragement of learning and achievement. The culture of competition among the students has been built one of them through excellent classes in every level. In addition, the principal also creates special achievement guidance courses in Mathematics and Science subjects taken from the third grade to sixth grade. This guidance also serves as a breeding activity of competitions such as the national science Olympiad and others. It is done in order to maintain and improve school image. The development of this competition culture will indirectly have implications for the establishment of a conducive learning environment. The competition culture built by the principal with these efforts has a positive correlation with achievement. If a community is given the stimulus and training for achievement then the outcome will be better than the community group which is not cultivated competition and achievements [32].

From the results of research and review of several theories, it can be concluded that the principal's efforts in developing the positive school culture through the development of harmonious relationships, the development of security in the school environment and the development of a conducive environment can gradually increase quality and achievement.

\section{The Impact of Positive School Culture to School Achievements.}

The development of positive school culture has an impact on school achievement. School achievement can be seen from the increase in the quantity of input every years and the student's academic and non-academic achievement. First, the increase of input quantity can be seen from the number of new students who participated in the registration of new student as shown in the figure 2 .

口

\section{Graphs of Registrants 2014-2017}

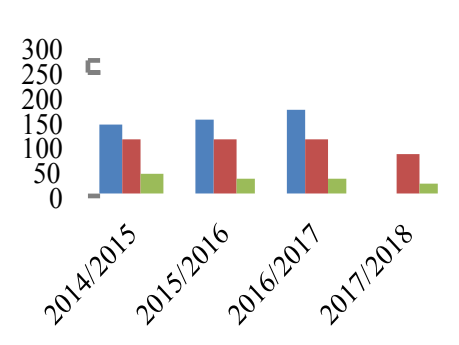

number of registrants

The number who passed

Class quota

Fig. 2. Data Analysis Components Source: Head of Administration School 
The figure above shows an increase in the number of applicants who enrolled in the last three years. It shows the achievement of school in several years. Second, school achievement can be seen also from student's achievement. This achievement cannot be separated from the growing school culture. Detail of student achievement on academic year 20162017 is that there have been 33 academic and non-academic competitions followed, i.e. $1^{\text {st }}$ winner 12 times, $2^{\text {nd }}$ winner 7 times, $3^{\text {rd }}$ winner 8 times and 6 times is the champion of hope. This achievement is the impact of a positive school culture developed by the principal. This impact supports the metaanalysis study of the relationship between school culture and student achievement in which this study reveals that school culture variable has a significant effect on student achievement [33].

\section{CONCLUSION}

The findings of the present study indicate that the leadership of principal is good. Participative leadership style applied is support positive school culture development. It is also supported by the roles of principal through the development of harmonious relationships, school security and school environment conducive to learning. Development of school cultures gives positive impact on school achievements.

\section{ACKNOWLEDGMENT}

I would like to thank all my lecturers and reviewers who have been willing to provide guidance, encouragement, feedback, and correction during the research process until this paper is completed.

\section{REFERENCES}

[1] K. Leithwood, K. Louis, S. Anderson, and K. Wahlstrom, How leadership influences student learning. New York: The Wallace Foundation, 2004.

[2] S. Habegger, "The Principal's Role in Successful Schools: Creating a Positive School Culture,” J. Princ., vol. 88, pp. 42-46, 2008.

[3] A. J. MacNeil, D. L. Prater, and S. Busch, "The effects of school culture and climate on student achievement," Int. J. Leadersh. Educ., vol. 12, no. 1, pp. 73-84, Jan. 2009.

[4] T. . Deal and K. . Peterson, "How leaders influence the culture of schools," vol. 56, pp. 28-30, 1998.

[5] R. Maslowski, "School culture: characteristics and levers for change," in B.P.M. Creemers e.a. (Eds.), Handboek Schoolorganisatie en Onderwijsmanagement, Alphen aan den Rijn: Samsom Tjeenk Willink, 1997, p. B1400/1-B1400/25.

[6] Peterson, K. D, and T. E, The Shaping School Culture Fieldbook. San Fransisco: The Jossey-Bass Education Series, 2002.

[7] D. T and P. K, Shaping school culture: The heart of leadership. San Fransisco: Jossey-Bass, 1999.

[8] K. J, Leading Change. Boston: Harvard Business Review Press, 2012.

[9] Sumarmi, "Membangun Kultur Sekolah," 2005. [Online]. Available: https://rivafauziah.wordpress.com/2005/06/26/membangun-kultursekolah/. [Accessed: 15-Nov-2016].

[10] Warsilah, Wijayanti, and Wiwik, "Principal Role in School Culture Development at UPT SD Moyu and Sleman District Indonesia," J. Akuntabilitas Manaj. Pendidik., vol. 3, no. 1, pp. 97-113, 2015.

[11] Y. G, Leadership in organizations 6th ed. Upper Saddle River NJ: Pearson-Prentice Hall, 2006.

[12] M. Fadhli, "Relationship between School Principals and School Culture With School Effectiveness in Junior High School Medan, Indonesia," Pelangi Pendidik., vol. 20, no. 1, 2013.
[13] P. Nurhanipah, "The Influence Of Organizational Culture And Academic Culture Of Teachers Towards School Achievement," J. Ilm. Mhs. Pascasarj. Adm. Pendidik., vol. 1, no. 2, p. 186, 2013.

[14] Yin and R. K, Case Study Research: Design and Methods. Calif: Sage Publication, 2003.

[15] N. E. G and M. Mitchell, Qualitative research: defining and designing. London: Sage Publication, 2013.

[16] N. Golafshani, "Understanding Reliability and Validity in Qualitative Research,” Qual. Rep., vol. 8, no. 4, pp. 597-606.

[17] M. B. Miles, M. H. A, and J. Saldana, Qualitative Data Analysis: A Methods Sourcebook, Third. California: Sage Publication, 2014.

[18] Hasibuan and Malayu, Manajemen Sumber Daya Manusia, Cetakan ke. Jakarta: PT. Bumi AKsara, 2007.

[19] M. Thoha, Kepimimpinan dalam Manajemen. Jakarta: PT. Raja Graafindo Persada, 2006.

[20] M. Ahearne, J. Mathieu, and A. Rapp, "To empower or not to empower your sales force? An empirical examination of the influence of leadership empowerment behaviour on customer satisfaction and performance," J. Appl. Psychol., vol. 90, pp. 945-955, 2005.

[21] X. Huang, I. J, A. Liu, and Y. Gong, "Does participative leadership enhance work performance by inducing empowerment or trust? The differential effects on managerial and non-managerial subordinates," J. Organ. Behav., vol. 31, no. 1, pp. 122-143, 2010.

[22] M. Timmerman, "How Participative Leadership Powers a Culture of Productivity," Worksapan The Magazine of WorldatWork Ed. 10, 2012.

[23] C. Bell, M. Chan, and P. Nel, "No TitleThe Impact of Participative and Directive Leadership on Organisational Culture: An Organisational Development Perspective," Mediterr. J. Soc. Sci., vol. 5, no. 23, pp. 1970-1985, 2014.

[24] I. Y. Gunawan, "National Education Policy in the Global Era concerning Value Education." [Online]. Available: http://p4tksbjogja.com. [Accessed: 15-Nov-2016].

[25] H. E. Mulyasa, Manajemen dan Kepemimpinan Kepala Sekolah, Cetakana k. Jakarta: Bumi AKsara, 2013.

[26] L. Lashway, Role of the School Leader. Eugene, OR: University of Oregon, 2003.

[27] Wahjosumidjo, Kepemimpinan Kepala Sekolah Tinjauan Teoritik dan Permasalahannya. Jakarta: Rajawali Pers, 2002.

[28] J. H. Stronge, H. B. Richard, and N. Catano, Kualitas Kepala Sekolah yang Efektif. Terj. Siti Mahyuni. Jakarta: PT Indeks, 2013.

[29] L. Barrios, S. . Jones, and S. S. Gallagher, "Legal Liability: The Consequences of School Injury,” J. Sch. Health, vol. 77, no. 5, pp. 273279.

[30] Sugiarti, "Strategic Factors Supporting School Performance at SMK Surakarta City,” J. Varia Pendidik., vol. 27, no. 2, pp. 174-182, 2015.

[31] B. Hurlock and Elizabeth, Perkembangan Anak. Jakarta: Erlangga, 1978.

[32] McClelland and D. C, The Achieving Society. Canada: D. Van Nostrand Company LTD, 1961.

[33] B. Fatih, Çoğaltay, Nazim, Karadağ, Engin, and A. Yusuf, "School Culture and Academic Achievement of Students: A Meta-analysis Study," Anthropologist, vol. 21, pp. 482-488, 2015. 